\title{
Characterization of Bone Substitute $\beta$-TCP Block for Maxillofacial Reconstruction
}

\author{
Caracterización del Bloque $\beta$-TCP de Sustitución Ósea para la reconstrucción Maxilofacial
}

\author{
Juan Pablo Alister ${ }^{1,2,3}$; Francisca Uribe ${ }^{1,2,3}$; Bélgica Vásquez ${ }^{4}$; Rodrigo Fariña ${ }^{5,6}$ \& Sergio Olate ${ }^{1,2,7}$
}

\begin{abstract}
ALISTER, J. P.; URIBE, F.; VÁSQUEZ, B.; FARIÑA, R. \& OLATE, S. Characterization of Bone Substitute $\beta$-TCP Block for Maxillofacial Reconstruction. Int. J. Morphol., 37(1):82-86, 2019.

SUMMARY: The aim of this study was to characterize a commercial beta tricalcium phosphate ( $\beta$-TCP) block allograft for use in maxillofacial reconstruction, evaluating its homogeneity, porosity and mineralization. Two commercial $5 \times 5 \times 10 \mathrm{~mm}$ chronOS Vivify $\beta$-TCP blocks were used, which were evaluated by a STEM SU-3500 variable pressure scanning electron microscope (SEM-STEM) (Hitachi, Japan). For the semi-quantitative microanalysis of elements, the QUANTAX 100 energy dispersive X-ray spectrometer detector (EDX) (Bruker, Germany) was used. The homogeneity of the structural morphology, macropore and micropore size and component homogeneity were evaluated. The microscopic analysis showed micropores of $164.92 \mathrm{~mm}( \pm 35.032 \mathrm{~mm})$ in diameter in the outer area and micropores in the inner area of $54.44 \mathrm{~mm}( \pm 17.676 \mathrm{~mm})$. The formation of porosities and irregularities present in the block was heterogeneous between the outer and inner surfaces. The mineral content of the blocks presented homogeneity with the presence of carbon $(2.02 \%)$, oxygen $(44.33 \%)$, phosphate $(16.62 \%)$ and calcium $(37.87 \%)$. The $\beta$-TCP block can be used in bone reconstruction but the presence of reduced macropore and micropore sizes could limit efficiency in the substitution and bone regeneration phase.
\end{abstract}

KEY WORDS: b-TCP; Scaffold; Craniofacial reconstruction; Bone graft.

\section{INTRODUCTION}

The craniomaxillofacial defects associated with tumors, trauma and their sequelae are frequent and present a variety of conditions; bone reconstruction is needed and must respond to esthetics and function, which determines a technically demanding process (Sándor et al., 2012; Fariña et al., 2016). The four essential properties in bone reconstruction - osteoconduction, osteoinduction, osteogenesis and osteopromotion (Ripamonti et al., 2001) are related to autogenous grafts, the gold standard in reconstruction. They bring together the best properties; however, the morbidity of the donor site is their main disadvantage (Pogrel et al., 1997).

Allografts and xenografts are subjected to various dehydration, sterilization and lyophilization treatments to reduce antigenicity reactions (Molly et al., 2008). But these lack osteogenic and osteopromoter properties, their osteinductive property has not been confirmed and they only present osteoconductive capacity (Busenlechner et al., 2008); their main disadvantage is related to the possibility of causing immunogenicity reactions and the transfer of diseases from the donor species (Eid et al., 2001).

Alloplastic grafts are totally synthetic substitutes, do not transmit diseases and have osteoconductive properties, such as hydroxyapatite, bioactive glass, calcium carbonate or tricalcium phosphate (LeGeros, 2002). These substitutes have become an accepted alternative in the reconstruction of small defects due to their ease of use and versatility. Their development and characterization continue to be relevant (Martinez et al., 2015), so that biocompatibility and time spent in the host are two decisive factors in their choice (Jensen et al., 2009; Araújo et al., 2011). In addition, their resorption is done through a process of synthesis, combining

\footnotetext{
${ }^{1} \mathrm{PhD}$ in Medical Science, Faculty of Medicine, Universidad de La Frontera, Chile.

${ }^{2}$ Department of Oral and Maxillofacial Surgery, Faculty of Dentistry, Universidad de La Frontera, Chile.

${ }^{3}$ Oral and Maxillofacial Surgery Unit, Hernán Henríquez Aravena Hospital, Chile.

${ }^{4}$ Facultad de Ciencias de la Salud, Universidad de Tarapacá, Arica, Chile.

${ }^{5}$ Department of Oral and Maxillofacial Surgery, Faculty of Dentistry, Universidad de Chile, Santiago, Chile.

${ }^{6}$ Oral and Maxillofacial Surgery Unit, Salvador Hospital, Santiago, Chile.

${ }^{7}$ Center for Excellence in Morphological and Surgical Studies, Universidad de La Frontera, Chile.
} 
the distribution of grain size, pore size and their porosity (Knabe et al., 2000; Daculsi et al., 2003; Cheng et al., 2013).

The aim of this study is to characterize a solid commercial $\beta$-TCP block for use in maxillofacial bone reconstruction using scanning electron microscopy.

\section{MATERIAL AND METHOD}

The study was conducted at the Center for Excellence in Morphological and Surgical Studies at the Universidad de La Frontera; two $5 \mathrm{~mm}$ x $5 \mathrm{~mm}$ x $10 \mathrm{~mm}\left(250 \mathrm{~mm}^{3}\right)$ blocks were selected, made with chronOS Vivify $\beta$-TCP (Synthes, Switzerland) for the study.

The products were removed from their packaging under sterile conditions to be placed on the analysis surface of a STEM SU-3500 variable pressure scanning electron microscope (SEM-STEM) (Hitachi, Japan), with a range of magnification variables and the detectors Everhart-Thornley secondary electron (SE) detector, backscattered electron (BSE) detector, compositional, topographic and 3D mode and a variable pressure ultradetector (UVD) STEM holder for transmission.

For the semi-quantitative microanalysis of elements, the QUANTAX 100 energy dispersive X-ray spectrometer detector (EDX) (Bruker, Germany) was used. The acquisition parameters of the images went to $15 \mathrm{kv}$, magnifications of 100x, 250X, 500x, 1000X and 4000x, capture speed "slow", vacuum time 2.23 seconds.

The study initially analyzed the external image of the block on all its sides to obtain data on mineral present,

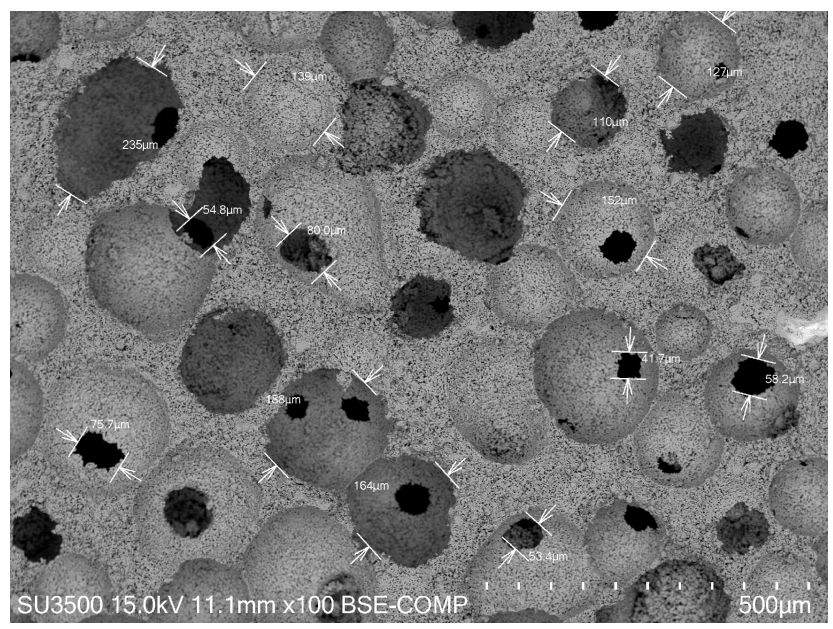

Fig. 1. View of the size of macro pores $(100 x)$ porosities of the block and ridges; later, maintaining the conditions of sterility, the block was sectioned in the middle part to divide it into two; the section was taken with a sterile saw blade installed in a low-speed motor (20,000 rpm). Then, the block was again installed on the image surface to identify the conditions observed inside the block, using the same type of analysis. The results were placed in a table designed on Microsoft Excel (Microsoft Corporation, USA), performing a descriptive analysis of the data.

\section{RESULTS}

The outer measurements revealed irregularities in the shape of the pores that were similar in the analyzed blocks; the macro pore diameters in these areas were on average $164.92 \mathrm{~mm}( \pm 35.032 \mathrm{~mm})$ with a range from $110 \mathrm{~mm}$ to $235 \mathrm{~mm}$ (Fig .1).

When the measurements of the inner area of the blocks were taken, differences were noted in the porosities compared to the outer layer, which was standard in the three analyzed blocks. An average diameter of the micro porosities was observed of $54.44 \mathrm{~mm}( \pm 17.676 \mathrm{~mm})$ with a range from $30 \mathrm{~mm}$ to $86 \mathrm{~mm}$ (Fig. 2). The formation of porosities and irregularities present in the block was heterogeneous between the outer and inner surfaces.

In terms of the mineral content of the blocks by semi-quantitative analysis, a standard condition of mineral concentrations was confirmed on the outer and inner surfaces of the blocks, demonstrating the homogeneity of this analysis with the presence of carbon $(2.02 \%)$, oxygen $(44.33 \%)$, phosphate $(16.62 \%)$ and calcium $(37.87 \%)$ (Fig. 3 and Table I).

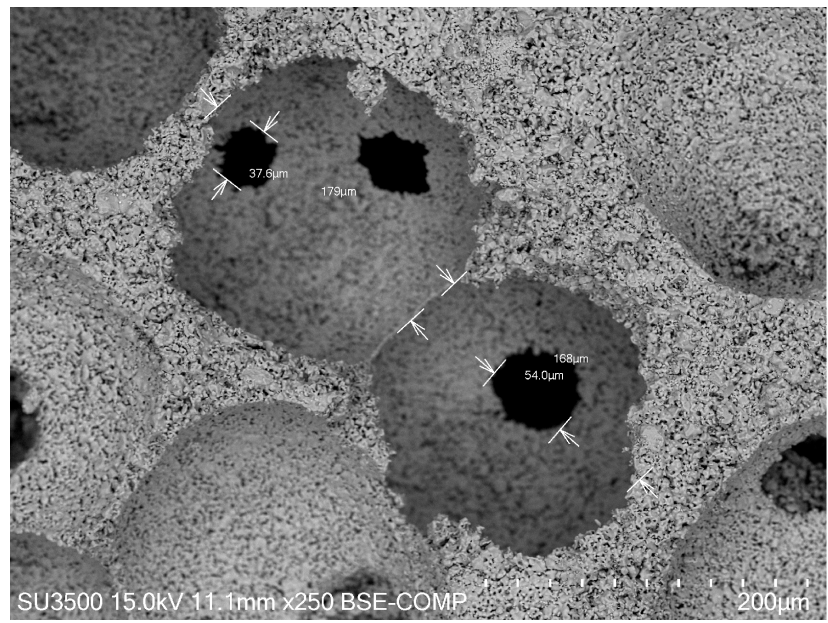

Fig. 2. View of the size of micro pores $(250 \mathrm{x})$ 


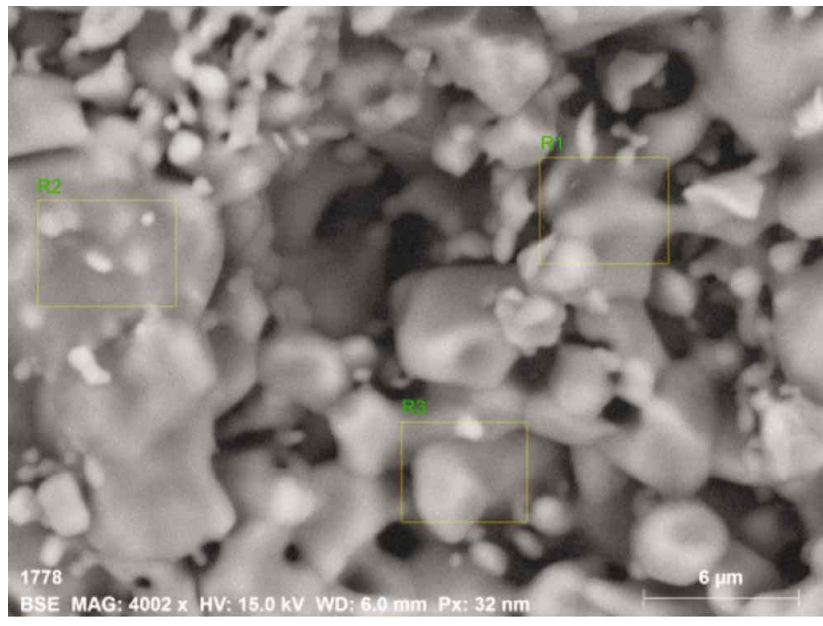

Fig. 3. Analysis area for the detection of mineral content of the blocks.

\section{DISCUSSION}

The synthetic substitutes or alloplastic grafts based on hydroxyapatite $(\mathrm{Ha})$, ceramic calcium phosphate and btricalcium phosphate are widely used as an alternative to autologous bone grafts in maxillofacial reconstruction (Spagnoli et al., 2001; Hoexter, 2002; Eppley et al., 2005). Several studies have shown these materials to be highly biocompatible, and they can also maintain the volume based on the capacity to regulate the resorption rate (Valentini \& Abensur, 1997; Schlee et al., 2014). The use of b-TCP has been applied as a scaffold in the reconstruction of craniomaxillofacial defects together with stem cells and morphogenetic protein (BMP) (Alister et al., 2016; Uribe et al., 2017).

New studies have focused on the development of scaffolds based on graft elements like b-TCP (Billström $e t$ al., 2013; Liu et al., 2014), where the porosity that enables cell colonization, biomechanical resistance and resorption is integrated in times that allow for the adequate replacement by newly formed bone tissue.

In our analysis of the microstructure of pores in the block, an average size of $164 \mathrm{~mm}$ was observed for macropores and an average of $54.4 \mathrm{~mm}$ for micropores; and when these results were compared with other developed matrices, we found significant differences, considering pore averages of 200 to $400 \mathrm{~mm}$ and interconnecting channels and micropores from 100 to $200 \mathrm{~mm}$ (Wang et al., 2006; Tanaka et al., 2008).

It has been noted that ideal sizes would be over 300 $\mathrm{mm}$ in order to favor and increase bone tissue and capillary
Table I. Mineral content of the blocks by semi-quantitative analysis.

\begin{tabular}{lllll}
\hline Spectrum & $\mathrm{C}$ & $\mathrm{O}$ & $\mathrm{P}$ & $\mathrm{Ca}$ \\
\hline $\mathrm{R} 1$ & 1.77 & 42.96 & 16.40 & 38.11 \\
$\mathrm{R} 2$ & 2.13 & 45.31 & 17.02 & 37.71 \\
$\mathrm{R} 3$ & 2.15 & 44.72 & 16.42 & 37.77 \\
Mean & 2.02 & 44.33 & 16.62 & 37.87 \\
sigma & 0.21 & 1.22 & 0.35 & 0.22 \\
Sigma mean & 0.12 & 0.71 & 0.20 & 0.13 \\
\hline
\end{tabular}

formation (Ohgushi et al., 1990; Karageorgiou \& Kaplan, 2005). However, having an ideal porous structure, as this increases the size of the support material to repair larger defects, the number of air bubbles contained within the block increases. Therefore, it becomes more complicated for the bone marrow stem cells (BMSC) to enter the block and for the in vitro culture medium to perfuse into the central areas of the porous support (Vunjak-Novakovic et al., 1998; Holy et al., 2000; Wendt et al., 2003).

If we analyze that the size of the mesenchymal cells varies according to their cell phase, they can have an average diameter of 19 to $26 \mathrm{~mm}$ (Ge et al., 2014; Majore et al., 2009; Marklein et al., 2016); our study shows macropores with theoretically suitable sizes (below the average indicated in the international literature), but with very small micropores and communication channels, in some cases similar to the size of cells, which could limit the incorporation of a cellular layer.

On the other hand, angiogenesis elements can also be limited with this pore structure. The sizes vary according to vascular type, such as approximately $5 \mathrm{~mm}$ capillaries, the microvessels that present between 10 and $50 \mathrm{~mm}$ and the arterioles that present from 40 to $300 \mathrm{~mm}$ (Chan \& Leong, 2008; Traore \& George, 2017); one of the challenges in the blocks and matrices for reconstruction is the limitation of the distance for oxygen diffusion (approximately from 100 to $200 \mathrm{~mm}$ ), the passage of nutrients and subsequent elimination of residues from the cell colonies (Lovett et al., 2009; Sakaguchi et al., 2013), so that the block analyzed in this study could have limitations in the substitution phase.

One positive aspect in this study is the homogeneity of mineral concentration, similar to those observed in other investigations (Daculsi et al., 1990; Miao \& Sun, 2010; Sheikh et al., 2015). The relation of mineral composition and their relation to porosity involves the resorption speed, which is mediated by demineralization in the first stage and then resorption by macrophages and osteoclasts.

The scaffold must be highly biocompatible, biodegradable, bioactive, and during healing it must promote 
osteoconduction, osteoinduction and osteogenesis. In addition, the scaffold must be osteoincorporative and osseointegrative to be accepted as part of the newly formed bone (Oryan et al., 2014; Moshiri et al., 2016). An ideal matrix block must imitate the native bone environment, macro- and microstructure, and must have a porous structure to allow the cells to enter the matrix to proliferate and be differentiated. This osteoconductive property is based to a large extent on the architecture of the block as well as on the materials used to make the desired matrix (Oryan et al.). The most important limitation during the healing of large bone defects is the lack of osteoinductivity of the matrices (Chen et al., 2010; Oryan et al.; Seo et al., 2014).

With the results of this study, it may be concluded that the b-TCP block can be used in bone reconstruction, but the presence of reduced micropore sizes could limit efficiency in the substitution and bone regeneration phase.

\section{ACKNOWLEDGEMENTS}

The authors are grateful for financing awarded by DIUFRO project DI17-0026 from the Research Office of the Universidad de La Frontera, Chile.

Author Francisca Uribe wish to thank the Comisión Nacional de Investigación Científica y Tecnológica, CONICYT, for financing their doctoral studies. CONICYTPCHA/doctoradonacional/2015-21150752.

ALISTER, J. P.; URIBE, F.; VÁSQUEZ, B.; FARIÑA, R. \& OLATE, S. Caracterización del bloque $\beta$-TCP de sustitución ósea para la reconstrucción maxilofacial. Int. J. Morphol., 37(1):82-86, 2019.

RESUMEN: El objetivo de este estudio fue caracterizar un aloinjerto de bloqueo de fosfato tricálcico ( $\beta$-TCP) comercial para su uso en la reconstrucción maxilofacial, evaluando su homogeneidad, porosidad y mineralización. Se utilizaron dos bloques comerciales de 5 × 5 x $10 \mathrm{~mm}$ de vivify $\beta$-TCP de chronOS, que se evaluaron mediante un microscopio electrónico de barrido de presión variable STEM SU-3500 (SEM-STEM) (Hitachi, Japón). Para el microanálisis de elementos semicuantitativo, se utilizó el detector de espectrómetro de rayos $\mathrm{X}$ de dispersión de energía QUANTAX 100 (EDX) (Bruker, Alemania). Se evaluó la homogeneidad de la morfología estructural, el tamaño del macroporo y microporo y la homogeneidad de los componentes. El análisis microscópico mostró microporos de 164,92 mm $( \pm 35,032 \mathrm{~mm})$ de diámetro en el área externa y microporos en el área interna de 54,44 $\mathrm{mm}( \pm 17,676 \mathrm{~mm})$. La formación de porosidades e irregularidades presentes en el bloque fue heterogénea entre las superficies externas e internas. El contenido mineral de los bloques presentó homogeneidad con la presencia de carbono $(2,02 \%)$, oxígeno $(44,33 \%)$, fosfato $(16,62 \%)$ y calcio $(37,87 \%)$. El bloque $\beta$-TCP se puede utilizar en la reconstrucción ósea, pero la presencia de macroporos y tamaños de microporos reducidos podría limitar la eficacia en la fase de sustitución y regeneración ósea.

PALABRAS CLAVE: b-TCP; Andamio; Reconstrucción craneofacial; Injerto óseo.

\section{REFERENCES}

Alister, J. P.; Uribe, F.; Alister, F.; Fariña, R. \& Olate, S. Stem cells in human cranio-maxillo-facial reconstruction. Int. J. Morphol., 34(4):1531-8, 2016.

Araújo, M. G.; Linder, E. \& Lindhe, J. Bio-Oss collagen in the buccal gap at immediate implants: a 6-month study in the dog. Clin. Oral Implants Res., 22(1):1-8, 2011.

Billström, G. H.; Blom, A. W.; Larsson, S. \& Beswick, A. D. Application of scaffolds for bone regeneration strategies: current trends and future directions. Injury, 44 Suppl. 1:S28-33, 2013.

Busenlechner, D.; Tangl, S.; Mair, B.; Fugger, G.; Gruber, R.; Redl, H. \& Watzek, G. Simultaneous in vivo comparison of bone substitutes in a guided bone regeneration model. Biomaterials, 29(2):3195-200, 2008.

Chan, B. P. \& Leong, K. W. Scaffolding in tissue engineering: general approaches and tissue-specific considerations. Eur. Spine J., 17 Suppl. 4:467-79, 2008.

Chen, P. Y.; Sun, J. S.; Tsuang, Y. H.; Chen, M. H.; Weng, P. W. \& Lin, F. H. Simvastatin promotes osteoblast viability and differentiation via Ras/ Smad/Erk/BMP-2 signaling pathway. Nutr. Res., 30(3):191-9, 2010.

Cheng, L.; Shi, Y.; Ye, F. \& Bu, H. Osteoinduction of calcium phosphate biomaterials in small animals. Mater. Sci. Eng. C Mater. Biol. Appl., 33(3):1254-60, 2013.

Daculsi, G.; Laboux, O.; Malard, O. \& Weiss, P. Current state of the art of biphasic calcium phosphate bioceramics. J. Mater. Sci. Mater. Med., 14(3):195-200, 2003.

Daculsi, G.; Passuti, N.; Martin, S.; Deudon, C.; Legeros, R. Z. \& Raher, $\mathrm{S}$. Macroporous calcium phosphate ceramic for long bone surgery in humans and dogs. Clinical and histological study. J. Biomed. Mater. Res., 24(3):379-96, 1990.

Eid, K.; Zelicof, S.; Perona, B. P.; Sledge, C. B. \& Glowacki, J. Tissue reactions to particles of bone-substitute materials in intraosseous and heterotopic sites in rats: discrimination of osteoinduction, osteocompatibility, and inflammation. J. Orthop. Res., 19(5):962-9, 2001.

Eppley, B. L.; Pietrzak, W. S. \& Blanton, M. W. Allograft and alloplastic bone substitutes: a review of science and technology for the craniomaxillofacial surgeon. J. Craniofac. Surg., 16(6):981-9, 2005.

Fariña, R.; Alister, J. P.; Uribe, F.; Olate, S. \& Arriagada, A. Indications of free grafts in mandibular reconstruction, after removing benign tumors: treatment algorithm. Plast. Reconstr. Surg. Glob. Open, 4(8):e845, 2016.

Ge, J.; Guo, L.; Wang, S.; Zhang, Y.; Cai, T.; Zhao, R. C. \& Wu, Y. The size of mesenchymal stem cells is a significant cause of vascular obstructions and stroke. Stem Cell Rev., 10(2):295-303, 2014.

Hoexter, D. L. Bone regeneration graft materials. J. Oral Implantol., 28(6):290-4, 2002.

Holy, C. E.; Shoichet, M. S. \& Davies, J. E. Engineering three-dimensional bone tissue in vitro using biodegradable scaffolds: investigating initial cell-seeding density and culture period. J. Biomed. Mater. Res., 51(3):376-82, 2000.

Jensen, S. S. \& Terheyden, H. Bone augmentation procedures in localized defects in the alveolar ridge: clinical results with different bone grafts and bone-substitute materials. Int. J. Oral Maxillofac. Implants, 24 Suppl.:218-36, 2009. 
Karageorgiou, V. \& Kaplan, D. Porosity of 3D biomaterial scaffolds and osteogenesis. Biomaterials, 26(27):5474-91, 2005.

Knabe, C.; Driessens, F. C.; Planell, J. A.; Gildenhaar, R.; Berger, G.; Reif, D.; Fitzner, R.; Radlanski, R. J. \& Gross, U. Evaluation of calcium phosphates and experimental calcium phosphate bone cements using osteogenic cultures. J. Biomed. Mater. Res., 52(3):498-508, 2000.

LeGeros, R. Z. Properties of osteoconductive biomaterials: calcium phosphates. Clin. Orthop. Relat. Res., (395):81-98, 2002.

Liu, C. K.; Jing, C. X.; Tan, X. Y.; Xu, J. \& Hu, M. Using three-dimensional porous internal titanium scaffold or allogenic bone scaffold for tissue-engineering condyle as a novel reconstruction of mandibular condylar defects. J. Med. Hypotheses Ideas, 8(2):69-73, 2014.

Lovett, M.; Lee, K.; Edwards, A. \& Kaplan, D. L. Vascularization strategies for tissue engineering. Tissue Eng. Part B Rev., 15(3):353-70, 2009.

Majore, I.; Moretti, P.; Hass, R. \& Kasper, C. Identification of subpopulations in mesenchymal stem cell-like cultures from human umbilical cord. Cell Commun. Signal., 7:6, 2009.

Marklein, R. A.; Lo Surdo, J. L.; Bellayr, I. H.; Godil, S. A.; Puri, R. K. \& Bauer, S. R. High Content Imaging of Early Morphological Signatures Predicts Long Term Mineralization Capacity of Human Mesenchymal Stem Cells upon Osteogenic Induction. Stem Cells, 34(4):935-47, 2016.

Martinez, A.; Balboa, O.; Gasamans, I.; Otero-Cepeda, X. L. \& Guitian, F. Deproteinated bovine bone vs. beta-tricalcium phosphate as bone graft substitutes: histomorphometric longitudinal study in the rabbit cranial vault. Clin. Oral Implants Res., 26(6):623-32, 2015.

Miao, X. \& Sun, D. Graded/gradient porous biomaterials. Materials (Basel), 3(1):26-47, 2010.

Molly, L.; Vandromme, H.; Quirynen, M.; Schepers, E.; Adams, J. L. \& van Steenberghe, D. Bone formation following implantation of bone biomaterials into extraction sites. J. Periodontol., 79(6):1108-15, 2008.

Moshiri, A.; Sharifi, A. M. \& Oryan, A. Role of Simvastatin on fracture healing and osteoporosis: a systematic review on in vivo investigations. Clin. Exp. Pharmacol. Physiol., 43(7):659-84, 2016.

Ohgushi, H.; Okumura, M.; Tamai, S.; Shors, E. C. \& Caplan, A. I. Marrow cell induced osteogenesis in porous hydroxyapatite and tricalcium phosphate: A comparative histomorphometric study of ectopic bone formation. J. Biomed. Mater. Res., 24(12):1563-70, 1990.

Oryan, A.; Alidadi, S.; Moshiri, A. \& Maffulli, N. Bone regenerative medicine: classic options, novel strategies, and future directions. J. Orthop. Surg. Res., 9(1):18, 2014.

Pogrel, M. A.; Podlesh, S.; Anthony, J. P. \& Alexander, J. A comparison of vascularized and nonvascularized bone grafts for reconstruction of mandibular continuity defects. J. Oral Maxillofac. Surg., 55(11):12006, 1997.

Ripamonti, U.; Ramoshebi, L. N.; Matsaba, T.; Tasker, J.; Crooks, J. \& Teare, J. Bone induction by BMPs/OPs and related family members in primates. J. Bone Joint Surg. Am., 83-A Suppl. 1 (Pt. 2):S116-27, 2001.

Sakaguchi, K.; Shimizu, T.; Horaguchi, S.; Sekine, H.; Yamato, M.; Umezu, M. \& Okano, T. In vitro engineering of vascularized tissue surrogates. Sci. Rep., 3:1316, 2013.

Sándor, G. K. B.; Carmichael, R. P.; Ylikontiola, L. P.; Jan, A.; Duval, M. G. \& Clokie, C. M. L. Healing of large dentofacial defects. Endod. Top., 25(1):63-94, 2012.

Schlee, M.; Dehner, J. F.; Baukloh, K.; Happe, A.; Seitz, O. \& Sader, R. Esthetic outcome of implant-based reconstructions in augmented bone: comparison of autologous and allogeneic bone block grafting with the pink esthetic score (PES). Head Face Med., 10:21, 2014.

Seo, J. P.; Tsuzuki, N.; Haneda, S.; Yamada, K.; Furuoka, H.; Tabata, Y. \& Sasaki, N. Osteoinductivity of gelatin/b-tricalcium phosphate sponges loaded with different concentrations of mesenchymal stem cells and bone morphogenetic protein-2 in an equine bone defect model. Vet. Res. Commun., 38(1):73-80, 2014.

Sheikh, Z.; Abdallah, M. N.; Hanafi, A. A.; Misbahuddin, S.; Rashid, H. \& Glogauer, M. Mechanisms of in vivo degradation and resorption of calcium phosphate based biomaterials. Materials (Basel), 8(11):7913$25,2015$.
Spagnoli, D.; Mazzonetto, R. \& Marchena, J. Clinical procedures currently using bone grafting with guided tissue regeneration techniques. Oral Maxillofac. Surg. Clin. North Am., 13:423-36, 2001.

Tanaka, T.; Kumagae, Y.; Saito, M.; Chazono, M.; Komaki, H.; Kikuchi, T.; Kitasato, S. \& Marumo, K. Bone formation and resorption in patients after implantation of beta-tricalcium phosphate blocks with $60 \%$ and $75 \%$ porosity in opening-wedge high tibial osteotomy. J. Biomed. Mater. Res. B Appl. Biomater., 86(2):453-9, 2008.

Traore, M. A. \& George, S. C. Tissue engineering the vascular tree. Tissue Eng. Part B Rev., 23(6):505-14, 2017.

Uribe, F.; Cantín, M.; Alister, J. P.; Vilos, C.; Fariña, R. \& Olate, S. Bone morphogenetic protein and its option as an alveolar cleft treatment. Int. J. Morphol., 35(1):310-8, 2017.

Valentini, P. \& Abensur, D. Maxillary sinus floor elevation for implant placement with demineralized freeze-dried bone and bovine bone (BioOss): a clinical study of 20 patients. Int. J. Periodontics Restorative Dent., 17(3):232-41, 1997.

Vunjak-Novakovic, G.; Obradovic, B.; Martin, I.; Bursac, P. M.; Langer, R. \& Freed, L. E. Dynamic cell seeding of polymer scaffolds for cartilage tissue engineering. Biotechnol. Prog., 14(2):193-202, 1998.

Wang, J.; Asou, Y.; Sekiya, I.; Sotome, S.; Orii, H. \& Shinomiya, K. Enhancement of tissue engineered bone formation by a low pressure system improving cell seeding and medium perfusion into a porous scaffold. Biomaterials, 27(13):2738-46, 2006.

Wendt, D.; Marsano, A.; Jakob, M.; Heberer, M. \& Martin, I. Oscillating perfusion of cell suspensions through three-dimensional scaffolds enhances cell seeding efficiency and uniformity. Biotechnol. Bioeng., 84(2):205-14, 2003

Corresponding author:

Juan Pablo Alister Herdener DDS OMFS PhD

Department of Oral and Maxillofacial Surgery

Faculty of Dentistry

Universidad de La Frontera

$\mathrm{PhD}$ in Medical Science

Faculty of Medicine

Universidad de La Frontera

Avenida Francisco Salazar 01145

Temuco

CHILE

Received: 04-09-2018

Accepted: 16-11-2018

Email: juan.alister@ufrontera.cl 